\title{
Surga Dan Neraka Dalam Persepsi Al-Ghazali
}

\author{
Oleh: Hanafi \\ hanafi@uinjkt.ac.id
}

\begin{abstract}
Abstrak : Ajaran tentang akhirat juga merupak pokok ajaran agama-agama Ibrahimik dan kepercayaan yang pernah ada sebelumnya. Hal ini dapat ditelusiri, misalnya pada bangsa Mesir Kuno, yang telah ada jauh sebelum Islam muncul, adalah bangsa yang dianggap pertama kali yang meyakini adanya kehidupan setelah kehidupan di dunia ini. Bagi al-Ghazali surga dan neraka adalah tempat manusia di kehidupan akhirat. Surga baginya tempat yang penuh kesenangan sedangkan neraka tempat penuh siksaan dan kesengsaraan.
\end{abstract}

Kata Kunci: surga, neraka, al-Ghazali

\section{A. Pendahuluan}

Islam merupakan agama yang mengajarkan kepada pengikutnya keyakinan akan adanya kehidupan akhirat, kehidupan setelah kematian. Ajaran ini merupakan salah satu pokok rukun Iman yang apabila diabaikan maka menyebabkan seseorang dianggap tidak beriman. Pentingnya ajaran ini terlihat dalam ayat-ayat al-Qur'an yang sering kali mendudukan akhirat dengan keyakinan terhadap Allah, Tuhan yang Maha Tunggal dan Maha Adil. Hal ini, misalnya dapat dipahami dari hadits yang diriwayatkan oleh Ahmad, Nasa'I, Ibnu Majah, Bukhari dan Muslim: "Barang siapa yang beriman kepada Allah dan Akhirat, hendaklah berlaku baik terhadap tetangganya. Dan barang siapa yang beriman kepada Allah dan akhirta hendaklah menghormati tamunya. Dan barang siapa yang beriman kepada Allah dan akhirat hendaklah berkata baik atau diam". ${ }^{1}$

Selain Islam, ajaran tentang akhirat juga merupak pokok ajaran agama-agama Ibrahimik dan kepercayaan yang pernah ada sebelumnya. Hal ini dapat ditelusiri, misalnya pada bangsa 
Mesir Kuno, yang telah ada jauh sebelum Islam muncul, adalah bangsa yang dianggap pertama kali yang meyakini adanya kehidupan setelah kehidupan di dunia ini. Menurut bangsa ini, ide pokok ajaran akhirat yang berisi ganjaran perbuatan selama di dunia, di jelaskan bersamaan dengan ide perpindahan jiwa manusia setelah mengalami kematian. ${ }^{2}$

Bangsa Mesir, sebagaimana dijelaskan Sayid Qutub, adalah para penyembah Osiris yang mempunyai prinsip utama yang mengajarkan bahwa setiap individu, baik para raja dan penguasa ataupun para rakyat biasa dan jelata akan dimintai pertanggungjawaban mereka di akhirat kelak atas segala perbuatan yang telah dilakukan selama menjalani kehidupan di dunia yang fana ini. Perbuatan kebaikan yang telah mereka lakukan di dunia akan diganjar dengan kenikmatan abadi, sebaliknya perbuatan buruk yang dikerjakan akan diberi sanksi dengan siksaan di dalam neraka. ${ }^{3}$

Bangsa Persi yang menganut ajaran Zoroaster berkeyakinan bahwa ketika seseorang menemui ajalnya, roh yang dimilikinya masih akan tetap ada di sampingnya selama tiga hari tiga malam dalam kondisi bahagia atau sengsara. Kemudian pada hari berikutnya, roh itu akan ditiup angin menuju suatu tempat yang berisi para gadis perawan nan cantik jelita dan para nenek berwajah seram yang menakutkan. Apabila pemilik roh tersebut menjalankan berbagai kebaikan selama di dunia dan berprilaku baik, maka ruhnya akan ditemani oleh para gadis cantik tersebut menuju jembatan perhitungan dan keputusan terakhir, namun apabila selama di dunia ia berperangai buruk dan melakukan tindakan yang tercela, maka ruhnya akan ditemani oleh para nenek yang menyeramkan ke jembatan perhitungan dan keputusan akhir.

Selanjutnya peristiwa berikutnya adalah pemberian vonis dengan menggunakan amal timbangan kebaikan. Apabila timbangan kebaikannya lebih berat ketimbang kejahatannya, maka jembatan tersebut akan melebar, sedangkan sebaliknya apabila timbangan kejahatannya lebih berat dari timbangan perbuatan kebaikannya, maka jembatan tersebut akan mengecil sampai sehalus rambut dan menjadi tajam selayaknya golok yang tajam Selanjutnya, mereka yang berhasil melewati 
jembatan tersebut akan mendapatkan kebahagiaan yang abadi, sedangkan mereka yang terjatuh dari jembatan tersebut akan tercebur ke dalam neraka yang gelap pekat. Sedangkan bagi mereka yang timbangan kebaikan dan keburukannya seimbang akan ditempatkan di suatu tempat yang amat luas seluas langit dan bumi, yang merupakan penantian mereka dalam menunggu keputusan akhir mereka. ${ }^{4}$.

Agama Yahudi, salah satu agama Ibrahimik, pada awalnya tidak membicarakan adanya kehidupan akhirat. Di dalam kitab Perjanjian Lama tidak dijumpai pembahasan mengenai kehidupan setelah kematian di alam akhirat. Agama ini mengajarkan kepada pengikutnya bahwa kebaikan dan kejahatan yang dilakukan seseorang akan dirasakan ketika menjalani kehidupan di dunia ini. Artinya, perbuatan seseorang akan berdampak pada kehidupannya selama di dunia, baik itu berdampak secara kelompok maupun individu. ${ }^{5}$

Bagi para penganut Kristen, ajaran tentang akhirat dapat dilihat dari istilah "Kerajaan Tuhan" dan "kehidupan abadi". Penganut agama ini meyakini bahwa setiap manusia yang menjalani kehidupan di dunia akan mendapatkan ganjaran yang setimpal sesuai dengan prilaku dan perbuatannya selama menjalani kehidupan. Orang yang melakukan perbuatan dosa akan dimasukkan ke dalam neraka yang abadi. Sedangkan orang yang banyak melakukan kebaikan akan diangkat ke kerajaan langit, di sana mereka akan duduk makan bersama dengan Abraham, Ishak dan Ayub. ${ }^{6}$

Dalam Islam, salah satu yang menjadi pokok pembicaraan kajian kehidupan akhirat adalah tema tentang surga dan neraka. Walaupun ayat-ayat al-Qur'an dan hadits banyak memberitakan tentang hal ini, namun terdapat beragam perbedaan interpretasi di kalangan cendikiawan Muslim dan ulama. Persoalan yang sering kali muncul dalam diskursus surga dan neraka di antaranya tentang gambaran fisik keduanya, kenikmatan di surga dan siksaan di neraka, balasan yang diterima bisa berupa balasan jasmani ataukah rohani, serta pencipataan keduanya.

Diskursus tentang yang tersebut di atas telah dibicarakan sejak zaman Nabi sampai dengan masa postmodern. Ketika Nabi 
Muhammad hidup, problematika yang berkaitan dengan surga dan neraka tidaklah muncul sehingga menimbulkan perdebatan yang berkepanjangan. Hal itu terjadi karena, para sahabat akan mengembalikan semua persoalan yang berkaitan dengan wahyu kepada Nabi, termasuk di dalamnya ajaran tentang surga dan neraka. Namun berdeda kondisinya setelah Nabi Muhammad wafat, persoalan-persoalan yang berkaitan dengan permasalahan metafisika seringkali memunculkan multi tafsir yang berbedabeda di kalangan cendikiawan Muslim, dan para Ulama'.

Salah satu tema yang muncul dalam diskursus surga dan neraka, seperti yang tersebut di atas adalah problematika penciptaan keduanya. Para cendikiawan Muslim dan para Ulama mempedebatkan keberadaan surga dan neraka. Permasalahan yang muncul apakah surga dan neraka telah diciptakan ataukah belum diciptakan? Perbedaan jawaban yang diberikan yang menimbulkan perbedaan pemahaman biasanya bermula dari perbedaan interpretasi ayat-ayat al-Qur'an dan hadits yang menyatakan hal tersebut. Jane Smith Idelman dalam karyanya yang telah diterjemahkan, Maut, Barzakh, Kiamat, Akhirat: Ragam Pandangan Islam dari Klasik hingga Modern, berpendapat bahwa pandangan yang menyatakan bahwa surga dan neraka telah diciptakan berpegang pada ayat-ayat al-Qur'an dan hadits yang mengarah pada hal yang demikian. Salah satu contoh adalah hadits yang menceritakan bahwa Nabi Muhammad diperlihatkan surga dan neraka dalam perjalanan Isra' dan Mi'rajnya. Berbeda dengan yang menolak anggapan bahwa surga dan neraka telah diciptakan, para cendikiawan Muslim dan ulama menggunakan logika rasional yang mengungkapkan bahwa sesuatu yang bersifat ukrawi sangatlah tidak mungkin untuk berwujud di alam materi, di dunia ini. Artinya adalah suatu hal yang tidak rasional untuk menerima eksistensi surga dan neraka yang bersifat ukhrawi di dunia fisik duniawi.

Di samping itu, Mereka juga menjadikan surah al-Qashash 88 yang menyatakan" segala sesuatu akan hancur dan musnah kecuali Allah" sebagai dalil yang dijadikan pegangan. Mereka beranggapan bahwa keberadaan surga dan neraka sekarang ini adalah tidak dapa diterima akal sehat manusia, karena pada hari 
kiamat tiba dengan ditiupkannya sangkakala oleh malaikat Israfil, segalanya akan hancur binasa kecuali, Allah swt. Mereka juga mengunggapan alasan lain tentang hal tersebut, bahwa penciptaan surga dan neraka sebelum kiamat tiba adalah hal yang sia-sia, karena keduanya tidak akan dipergunakan dalam jangka waktu yang amat sangat lama, padahal Allah mustahil untuk berbuat yang sia-sia. ${ }^{7}$

Persoalan lain yang juga seringkali dibicarakan tentang surga dan neraka adalah tentang keabadian keduanya bersamaan dengan kekekalan para penghuninya dan segala kenikmatan dan siksaan keduanya. Di samping itu, diskursus yang tak pernah ditinggalkan dalam membicarakan ganjaran kenikmatan surga dan siksa neraka adalah, apakah kenikmatan dan siksaan dirasakan oleh jasmani, ruhani ataukah keduanya.

Dari problematika yang disebutkan di atas, beragam interpretasi dan pandangan diungkapkan oleh para cendikiawan Muslim dan Ulama'. Pandangan yang mengungkapkan bahwa sesungguhnya diakhirat kelak, kenikmatan surga dan perihnya siksaan neraka hanya akan dialami oleh ruh dilandaskan atas pendapat yang menyatakan bahwa di akhirat kelak yang akan dibangkitkan adalah ruh, maka, atas dasar ini, maka kenikmatan dan siksaan di surga dan neraka hanya akan dirasakan oleh ruh saja. Sedangkan mereka yang berpendapat bahwa kenikmatan surga dan siksa neraka akan dirasakan oleh jasmani dan ruhani, melandasan pandangan mereka di atas prinsip kemahakuasaan Tuhan, yang Mampu menciptakan apapun atas kehendakNya, sekalipun dari ketiadaan. Atas dasar ini, mereka beranggapan bahwa Allah juga mampu untuk membangkitkan jasad manusia yang telah hancur ke dalam bentuknya yang semula, sehingga jasmani dan ruhani dapat merasakan kenikmatan surga dan siksa neraka. ${ }^{8}$

Dari sekian banyaknya Cendikiawan Muslim dan ulama yang mencoba menginterpretasi ayat-ayat al-Qur'an yang berkaitan dengan permasalahan surga dan neraka, penulis tertarik untuk menghadirkan pemikiran al-Ghazali dalam memberikan alternatif pemahaman metafisika akhirat tersebut. Bagi penulis kejeniusan beliau dalam pemikiran Islam layak 
untuk dikemukakan dan dikaji secara serius untuk mendapatkan pemahaman yang komprehensip terhadap persoalan bertema surga dan neraka.

Reputasi Al-Ghazali dalam lapangan kajian pemikiran Islam telah diakui oleh para cendikiawan Muslim dan ulama'. Al-Taftazani, penulis buku tasauf yang banyak dijadikan rujukan, menyebutnya sebagai salah seorang sufi terbesar yang memiliki pengaruh yang sangat besar di bidang tasauf. ${ }^{9}$ Abdul Qayyum, penulis buku Surat-Surat Al-Ghazali kepada Para Penguasa, Pejabat Negara dan Ulama Sezamannya mengungkapkan bahwa Al-Ghazali adalah tokoh ilmuan Islam yang memiliki pengaruh yang sangat besar di dunia Islam, tanpa kehadirannya niscaya pada abad belakangan ini orang akan menyaksikan pudarnya ilmu-ilmu agama dan akhlak Islam. ${ }^{10}$ Sedangkan Nurcholish Madjid, tokoh modernis Indonesia memberikan komentar simpatik terhadap koprah Al-Ghazali dalam kancah polemic pemikiran Islam. Menurutnya, AlGhazali adalah tokoh yang telah menyelesaikan konflik yang telah terjadi, bukan hanya antara sufisme dan fiqih, tetapi juga antara sufisme dan kalam. ${ }^{11}$

Surga dan neraka adalah salah satu tema diskursus tentang akhirat yang selalu relevan dalam pemikiran Islam, namun selalu saja menyisakan pertanyaan lain yang menggelitik untuk terus dicoba disingkap tabir yang menyelimutinya.Dalam kajian ini penulis akan membatasi problematika akhirat yang berkenaan dengan konsep surga dan neraka dalam perspektif AlGhazali.

\section{B. Konsep Surga dalam Perspektif Al-Ghazali}

Bagi mayoritas penganut agama Islam, surga dan neraka merupakan tempat akhir manusia setelah dibangkitkan pada hari kiamat kelak. Mereka yang banyak berbuat amal kebaikan sebagaimana yang diperintahkan Allah sesuai pedoman ajaran Nabi Muhammad akan ditempatkan di surga, sedangkan mereka yang berprilaku sebaliknya akan ditempatkan di neraka.

Namun demikian para ulama dan cendikian Islam memiliki penjelasan yang tak seragam tentang detail akan surga 
dan neraka. Pada tulisan ini, akan dipaparkan bagaimana konsep surga dan neraka menurut Al-Ghazali.

\section{Pengertian Surga.}

Surga adalah istilah yang digunakan dalam bahasa Indonesia untuk mengartikan kata bahasa Arab,jannah. Term Jannah berasal dari akar kata yang terdiri dari huruf jīm, dan $n \bar{u} n$. Dari dua kata tersebut, janna berarti menutupi, sedangkan jannah memiliki memiliki arti asli, kebun atau perkebunan. Dalam term agama al-jannah berarti tempat yang disediakan oleh Allah untuk orang-orang yang bertakwa padaNya, berbakti serta taat dalam menjalankan perintahNya, dan menjauhi segala laranganNya. ${ }^{12}$ Masyarakat Arab seringkali memaknai kata jannah sebagai suatu tempat yang berisi pohon-pohon rindang, yang berisi kurma dan anggur sehingga tanahnya tertutupi oleh kedua jenis pohon tersebut. Tetapi jika tempat tersebut hanya terisi oleh pepohonan dari jenis berbeda selain kurma dan anggur, mereka biasanya menyebut dengan kata hadiqah.$^{13}$

Al-Ghazali tidak memberikan pengertian surga secara definitif, namun demikian dari penjelasan yang ia berikan dapat dimengerti bahwa surga adalah tempat yang tidak terdapat kesedihan dan kesusahan. Ia adalah tempat yang dipenuhi oleh kenikmatan dan kebahagiaan yang abadi. ${ }^{14}$

Kata Jannah dalam artian eskatologis di dalam al-Qur'an disebutkan sebanyak 45 kali dalam bentuk tunggal, dan dua kali dalam bentuk mutsannā, dan 69 kali dalam bentuk jamak. Dalam bentuk tunggal kata jannah merujuk kepada satu entitas yaitu keseluruhan tempat tinggal bagi orang-orang yang saleh, yang berlawanan dengan neraka yang merupakan tempat tinggal orang-orang yang jahat. Sedangkan penggunaan kata dalam bentuk jamak, merupakan salah satu contoh dari cirri khas gaya bahasa al-Qur'an yang dengannya deskripsi tentang surga benarbenar memberikan kesan kelimpahan kenikmatan yang tak terbatas. $^{15}$

Di dalam al-Qur'an terdapat beberapa nama sebutan untuk surga, yaitu: 
1. Jannah al-Firdaus, terdapat dalam Q:S al-Kahfi 18: 107-108,"Sesungguhnya orang-orang yang beriman dan mengerjakan amal saleh, maka bagi mereka adalah surga Firdaus. Mereka kekal di dalamnya , dan mereka tidak ingin pindah dari sana."

2. Jannah al- 'Adn, terdapat dalam Q:S al-Kahfi 18, 3031, "Sesungguhnya orang-orang yang beriman dan mengerjakan amal saleh, tentu Kami tidak akan mengabaikan orang-orang yang melakukan perbuatan baik itu. Untuk mereka surga Adn yang mengalir sungai di bawahnya.."

3. Jannah al-Na'ìm, terdapat dalam Q:S Luqmān 31: 89, "Sesungguhnya orang-orang yang beriman dan mengerjakan amal saleh, bagi mereka surga na'īm, mereka kekal di dalamnya. Janji Allah pasti. Dan Dia maha Perkasa lagi Maha Bijaksana."

4. Jannah al-Ma'wā, terdapat dalam Q:S al-Sajadah 32: 19," Adapun orang-orang yang beriman dan mengerjakan amal saleh; mereka akan memperoleh surga ma'wā untuk kediaman mereka, sebagai balasan dari semua amal perbuatan yang dikerjakan."

5. Dār al-Salām, terdapat dalam Q:S Yūnus 10:25, "Dan Allah mengajak ke surga Dār al Salām, dan Dia menunjukkan orang yang dikehendaki kepada jalan yang lurus."

6. Dār al-Muqāmah, terdapat dalam Q:S Fathr 35: 3435,"Orang-orang ahli surga itu mengucapkan: Segala puji bagi Allah yang telah melenyapkan kesusahan dari kita semua. Sesungguhnya Tuhan kita adalah Maha Pengampun lagi Maha Pemurah. Dia telah menempatkan kita di Dār al-Muqāah, yakni negeri kekal yaitu surga dengan karuniaNya. Di situ kita tidak merasa lelah dan resah."

7. Al-Maqūm al-Amīn, Terdapat dalam Q:S al-Dukhān 44:51, "Sesungguhnya orang-orang yang bertaqwa akan memperoleh al-maqām al-amin (tempat yang aman)."16 
Mayoritas ulama dan cendikiawan muslim menganggap bahwa diskursus tentang surga adalah permasalahan yang berkaitan dengan sam'iyyat,. Oleh karena itu interpretasi yang diberikan hanya mereka dasarkan pada informasi yang terdapat dalam al-Qur'an dan al-hadits. Demikian pula dengan alGhazali, penjelasan dan keterangan yang beliau berikan dalam kajian tentang surga dan neraka selalu berdasarkan apa yang alQur'an dan hadits ungkapkan. Hal ini terlihat bagaimana ketika beliau menguraikan tentang penghuni surga.

\section{Penghuni Surga}

Dalam al-Qur'an, kitab suci yang diyakini oleh ummat Islam sebagai mukjizat terbesar Nabi Muhammad yang merupakan petunjuk bagi orang beriman, banyak ayat-ayat yang berbicara tentang surga. Uraian yang cukup detail akan gambaran penghuni surga dapat dijumpai khususnya pada suratsurat al-Wāqi'ah, al-Rahmān, al-insdan al-Ghāshiyah. Dalam ayat-ayat yang terdapat dalam surat al-Rahmānayat 46 sampai 76 dijelaskan: “...Dan bagi orang yang takut akan saat menghadap Tuhannya ada dua surga (46), Maka nikmat Tuhan kamu yang manakah yang kamu dustakan? (47)Kedua surga itu mempunyai pohon-pohonan dan buah-buahan (48) Maka nikmat Tuhan kamu yang manakah yang kamu dustakan? (49). Di dalam kedua surga itu ada dua buah mata air yang mengalir (50). Maka nikmat Tuhan kamu yang manakah yang kamu dustakan? (51). Di dalam kedua surga itu terdapat segala macam buah-buahan yang berpasangan (52). Maka nikmat Tuhan kamu yang manakah yang kamu dustakan? (53) Mereka bertelekan di atas permadani yang di sebelah dalamnya dari sutra. Dan buahbuahan darri kedua surga tersebut dapat dipetik dari dekat. (54) Maka nikmat Tuhan kamu yang manakah yang kamu dustakan? (55). Di dalam surga itu ada bidadari-bidadari yang sopan menundukan pandangannya, tidak pernah disentuh manusia sebelum mereka (penghuni-penghuni surga yang menjadi suami mereka) dan tidak pula oleh jin. (56). Maka nikmat Tuhan kamu yang manakah yang kamu dustakan? (57). Seakan-akan bidadari itu permata yakut dan marjan. (58). Tidak ada balasan kebaikan 
kecuali kebaikan pula. (59). Maka nikmat Tuhan kamu yang manakah yang kamu dustakan? (60). Dan selain dari dua surga itu ada dua surga lagi. (61) Maka nikmat Tuhan kamu yang manakah yang kamu dustakan? (62). Kedua surga itu (kelihatan) hijau tua warnanya. (63) Maka nikmat Tuhan kamu yang manakah yang kamu dustakan?.(64). Di dalam keduanya ada ada macam-macan buah dan kurma serta delima. (65) Maka nikmat Tuhan kamu yang manakah yang kamu dustakan?...(69). Di dalam surga itu ada bidadari-bidadari yang baik dan cantik.(70) Maka nikmat Tuhan kamu yang manakah yang kamu dustakan?(71). Bidadari-bidadari yang jelita., putih bersih dipingit dalam rumah. (72) Maka nikmat Tuhan kamu yang manakah yang kamu dustakan? (73). Mereka tidak pernah disentuh oleh manusia sebelum mereka dan tidak pula oleh jin. (74). Maka nikmat Tuhan kamu yang manakah yang kamu dustakan?. (75). Mereka bertelekkan pada bantal-bantal yang hijau dan pemadani-permadani yang indah. (76)..."

Dari ayat-ayat tersebut di atas dapat dimengerti bahwa Allah akan menjanjikan dua surga bagi hambaNya yang takwa dan takut akan siksaNya. Di dalam kedua surga itu terdapat berbagai jenis pohon dan buah-buahan. Di sana juga terdapat dua buah mata air yang selalu mengalir. Di samping itu ada juga berbagai macam buah-buahan yang berpasangan. Di mana buahbuahan tersebut amat mudah untuk dipetik. Para penghuni kedua surga tersebut berbaring di atas permadani yang bagian dalamnya terbuat dari sutra. Di ke dua surga itu ada bidadaribidadari yang sopan dan suci. Mereka tidak pernah disentuh oleh manusia dan jin. Mereka bagaikan permata yakut dan marjan.

Selain dua surga yang tersebut di atas, ada juga dua surga lainnya yang berwarna hijau tua. Di dalamnya terdapat dua mata air yang memancar. Di samping itu terdapat juga beraneka ragam buah-buahan, kurma, dan delima. Juga terdapat para bidadari nan cantik jelita, yang tak pernah disentuh oleh manusia dan jin. Para pe3nghuninya bersandar pada bantalbantal hijau dan permadani yang indah. ${ }^{17}$

Dalam Surat al-Wāqi'ah ayat 15-26: “...Mereka berada di atas dipan yang bertahtakan emas dan permata (15). Seraya 
bertelekan di atasnya berhadap-hadapan (16). Mereka oleh anakanak muda yang tetap muda(17). Dengan gelas-gelas dan pialapiala dari ma'in (18) mereka tidak pening karenanya dan tidak pula mabuk (19). Dan buah-buahan dari apa yang mereka pilih (20) Dan daging burung dari apa yang mereka inginkan(21). Dan ada bidadari -bidadari yang bermata jeli (22). Laksana mutiara yang tersimpan baik (23). Sebagai balasan bagi apa yang telah mereka kerjakan (24). Mereka tidak mendengar di dalamnya parkataan yang sia-sia dan tidak pula perkataan yang menimbulkan dosa (25). Akan tetapi mereka mendengar ucapan salam $(26) \ldots$ “.

Dari ayat-ayat tersebut di atas dapat diketahui bahwa di surga nanti, para penghuninya akan duduk bersandar berhadaphadapan di atas dipan yang bertahtakan emas dan permata, dikelilingi oleh para pemuda yang awet muda dengan membawa gelas, cerek dan seloki berisi minuman yang diambil dari air yang mengalir. Mereka tidak akan merasakan pening dan mabuk karenanya. Selain itu terdapat pula buah-buahan dari apa yang mereka pilih dan daging burung dari apa yang mereka inginkan.

Di samping itu, ada juga bidadari-bidadari yang bermata jeli, bagaikan mutiara yang tersimpan dengan baik, sebagai balasan terhadap apa yang pernah perbuat. Di dalam surga tersebut, mereka tidak mendengar kata yang sia-sia, dan juga perkataaan yang menimbulkan dosa, sebaliknya, mereka mendengarkan ucapan salam.

Dalam surat al-Kahfi ayat 31 dijelaskan bahwa, "para penghuni surga akan hidup dalam kebahagiaan seutuhnya, mereka dihiasi dengan gelang emas, mereka memakai pakaian hijau dari sutra halus dan tebal" . Kebahagiaan para penghuni surga juga digambarkan Allah sebagai mana terdapat dalam surat-surat al-Insan ayat 19 bahwa, "para penghuni surga dikelilingi oleh para pelayan yang awet muda. Jika engkau melihatnya, niscaya engkau mengira mereka adalah mutiaramutiara yang bertaburab".

Dalam surat Fushilat ayat 31, "Kamilah pelindungpelindungmu dalam kehidupan dunia dan akhirat; di dalamnya kamu memperoleh apa yang kamu inginkan dan memperoleh 
(pula) di dalamnya apa yang kamu minta." Dari ayat tersebut disebutkan bahwa para penghuni surga akan mendapatkan apa yang mereka inginkan, dan memproleh apa yang mereka minta. ${ }^{18}$

Gambaran-gambaran di atas menunjukkan bahwa surga adalah tempat yang dipenuhi dengan keindahan yang biasanya didambakan oleh manusia ketika mereka menjalani kehidupan dunia. Dari sini muncul pertanyaan apakah hal-hal yang digambarkan tersebut merupakan gambaran yang akan didapatkan manusia ketika menjalani kehidupan di surga? Artinya apakah kebahagiaan yang akan diterima oleh para penghuni surga adalah kebahagiaan yang sama dengan kebahagiaan di dunia?

Al-Ghazali dalam uraiannya tentang hal-hal yang berhubungan dengan surga dan kehidupan di dalamnya, nampaknya tidak dapat melepaskan diri dari apa yang telah termaktub dalam al-Qur'an. Beliau menginterpretasi ayat-ayat al-Qur'an yang berkaitan dengan surga dengan menggunakan bahasanya sendiri dengan rangkuman yang intinya tidak berbeda dengan arti harfiah yang ada. Penjelasan tentang surga dan halhala yang berkaitan dengannya digambarkan oleh al-Ghazali dengan gambaran fisik (jasmani). Hal ini ia pedomani dengan alasan bahwa tidak ada penjelasan yang dapat diterima kecuali sebagaimana yang telah Allah jelaskan dalam ayat-ayatNYa. Baginya para penghuni surga akan diberi minum dengan minuman yang lezat, mereka duduk di atas tempat yang terbuat dari mutiara yakut merah yang indah, dan dikelilingi hamparan permadani hijau yang memukaau. Mereka ditemani oleh para bidadari cantik, berpakaian sutra, bermahkota mutiara, dimana kesucian mereka belum pernah disentuh oleh siapapun. Para penghuni surga adalah raja-raja yang menikmati kesenangan yang beragam dan tak henti-hentinya sesuai dengan hasrat dan keinginan mereka.19

Kondisi fisik surga juga ia jelaskan sesuai dengan apa yang termaktub dalam ayat-ayat al-Qur'an dan hadits-hadits Nabi secara harfiah. Ia mengganbarkan bahwa sebagaimanadisebutkan dalam surat al-Rahmān ayat 63, -surga itu ada dua macam, yaitu yang terbuat dari emas dan perak. Ia 
juga menggambarkan bahwa surga mempunyai pintu-pintu dan kamar-kamar. Masing-masing pintu dan kamar akan dilalui dan dihuni oleh para penghuni sesuai dengan derajat dan amal kebajikannya.

Gambaran yang diberikan Al-Ghazali tentang kondisi surga dan apa-apa yang terdapat di dalamnya, merupakan gambaran yang ia ambil dari al=Qur'an dan hadits-hadits Nabi dengan pemahaman tekstual secara harfiah. Ia tidak berusaha memberikan makna khusus atau artian alegoris terhadap istilahistilah al-Qur'an dan hadits-hadits Nabi yang berkaitan dengan surga dan neraka. Untuk itu ia hanya menjelaskan kondisi surga sesuai dengan apa yang ia dapatkan dari al-Qur'an dan haditshadits Nabi.

Dalam menjelaskan rincian kondisi dan keadaan surga yang diambilnya dari dua sumber pokok ajaran Islam tersebut, ia membagi pada hal yang berkaitan dengan surga, dan penghuninya. Dalam membicarakan fisik surga, ia berusaha menjelaskan sifat dinding surga, tanah-tanahnya, pepohonannya dan sungai-sungai yang terdapat di dalamnya. Sedangkan dalam mengelaborasi penghuni surga, ia hanya menjelaskan hal-hal yang berkaitan dengan sifat pakaian, permadani, tempat tidur, tempat sandaran, tenda-tenda, makanan dan minuman yang akan mereka dapatkan. Di samping itu, juga kenikmatan-kenikmatan yang akan mereka rasakan.

\section{Penjelasn Fisik Surga Sebagai Tempat Balasan}

Mengenai fisik surga, Al-Ghazali menjelaskan bahwa didnding surga, -sebagaimana ia kutip dari hadits yang diriwayatkan oleh al-Tirmidzi adalah terbuat dari perak dan emas, sedangkan tanahnya adalah zafaran dan lumpurnya adalah kasturi. Pada keterangan lain, dengan berbasis pada hadits yang diriwatkan oleh Muslim, ia menyebutkan bahwa tanah surga adalah mutiara putih, yang harumnya beraroma kasturi murni. Sedangkan sungai sungai di surga adalah sungai yang sumber airnya memancar dari bawah bukit atau gunung kasturi. Akan halnya pepohonan surga, ia mengutip Q:S al- Wāqi'ah, ayat 30: Yang menyebutkan bahwa," Pohon di surga memiliki naungan 
yang amat luas, yang makna ukurannya sama dengan apabila seorang berjalan selama seratus tahun. ${ }^{20}$

Sementara itu, dalam menggambarkan apa-apa yang akan dikenakan oleh para penghuni surga, al-Ghazali mengutip Q:S al-Haj ayat 23: "Sesungguhnya Allah memasukan orang-orang beriman dan mengerjakan amal saleh kedalam surga-surga yang di bawahnya mengalir sungai-sungai. Di surga itu mereka diberi perhiasan dengan gelang-gelang dari emas dan mutiara, dan pakaian mereka adalah sutra.". Pada ayat tersebut dinyatakan bahwa penghuni surga akan mengenakan pakaian dari sutra, dan gelang-gelang yang terbuat dari emas dan mutiara. Ia juga mengutip hadits Nabi dari Abu Hurairah, yang diriwatkan oleh Muslim, yang menyatakan bahwa pakaian penghuni surga tidak akan hancur. Selanjutnya ia juga mengutip hadits yang diriwayatkan al-Tirmidzi, yang menyatakan bahwa penghuni surga akan mengenakan mahkota permata yang sinarnya dapat menerangi antara timur dan barat. Selain itu, para penghuni surga juga akan menempati tenda yang terbuat dari mutiara yang panjangnya enam puluh mil, dan memiliki 40.000 dau pintu yang terbuat dari emas. Pernyataan ini ia ambil dari hadits Muttafaq alaih.

Mengenai kondisi fisik para penghuni surga, ia menjelaskan bahwa, mereka akan terus awet muda. Hal ini sesuai dengan hadits yang diriwayatkan oleh Muslim. Ia juaga menyatakan bahwa wajah orang-orang yang masuk surga pertama kalai bagaikan rupa bulan purnama. Mereka tidak meludah, beringus ataupun buang hajat di surga. Keringat mereka adalah kasturi. Hala ini aia sandarkan pada hadits yan $g$ diriwayatkan oleh Muttafaq 'alaihi. ${ }^{21}$

Tentang makanan dan minuman yang akan didapatkan oleh para penghuni surga, al-Ghazali menyatakan bahwa mereka akan mendapatkan berbagai jenis buah-buahan, burung-burung, manna, salwa, madu, susu, dan jenis makanan lainnya yang tidak dapat dihitung. Hal ini sebagai mana terdapat dalam Q:S al-Baqarah 2: 25, "Setiap mereka diberi rizki buah-buahan dalam surga itu, mereka mengatakan :"'inilah yang pernah diberikan kepada kami dahulu. Mereka diberi buah-buahan yang serupa ...". 22 
Al-Ghazali meringkas keterangan hadits-hadits yang menggambarkan sifat-sifat surga dengan mengutip ungkapan Hasan Basri, " Sesengguhnya buah delimanya itu adalah seperti timba dan sesungguhnya sungai-sungainya adalah dari air susu yang tidak berubah rasanya, sungai-sungai dari aiar madu yang murni yang tidak adapat disifati oleh kau laki-laki dan sungaisungai dari khamar yang lezat bavi orang-orang yang minum yang tidak melemahkan akal pikiran, dan kepala tidak pusing karenanya. Dan sesungguhnya di dalam surga ada sesuatu yang tidak pernah mata melihatnya dan tidak pernah telinga mendengarnya dan tidak ada goresan atas hati manusia. Rajaraja yang bersenang senang yang berumur 33tahun dalam satu usia. Tinggi mereka adalah 60 hasta di langit, bercelak, tidak berbulu serta muda belia. Mereka aman dari azab dan rumah mereka tenang dengan mereka. Dan sesungguhnya sengaisungainya itu mengalir di atas batu-batu kecil dari yakut dan zabarzat. Dan sesungguhnya aurat-auratnya, pohon kurmanya, dan pohon anggurnya adalah mutiara. Dan buah-buahannya tidak diketahui kecuali oleh Allah swt. Dan sesungguhnya bau harumnya itu dapat dirasakan dari perjalanan 500 tahun. Dan sesungguhnya bagi mereka di surga ada kuda dan unta yang cepat berjalannya. Dan tali kekangnya dan pelananya adalah dari Yakut. Mereka saling mengunjungi di dalam surga. Dan istriistri mereka adalah bidadari. Seolah-olah mereka adalah telur yang tersimpan. Dan sesungguhnya seorang wanita itu mengambil diantara dua jarinya 70 pakaian, lalu ia memakainya. Maka dapat dilihat sum sum betisnya dari belakang 70 pakaian itu. Allah telah mensucikan akhlak dari sifat yang jahat, dan tubuh dari kematian. Mereka tidak beringus di dalam surga, dan tidak kencing dan tidak berak. Hanya saja itu adalah sendawa dan keringat minyak kasturi bagi mereka rizki mereka di surga pada pagi hari dan sore hari. Ingatlah bahwa malam tidak mengembalikan pada pagi hari kepada sore hari, dan sore hari kepada pagi hari. Dan sesungguhnya orang yang terakhir masuk surga dan serendah-rendah kedudukannya adalah dipanjangkan baginya penglihatannya dan kerajaanNya selama perjalanan seratus tahun pada istana-istana dari emas dan 
perak, dan tenda dari mutiara dan dilapangkan baginya dalam penglihatannya, sehingga ia memandang kepada sejauh-jauhnya sebagaimana ia memandang kepada sedekat-dekatnya.Diberi makan pagi atas mereka dengan 70.000 piring dari emas dan perak, dan diberi makan sore atas mereka dengan yang seperti itu. Dan ia mendapatkan rasa penghabisannya seperti ia mendapatkan rasa permulaannya. Dan sesungguhnya di surga ada yakut yang di atasnya 70.000 rumah. Pada setiap rumah ada 70.000 tempat tinggal yang tidak ada padanya pecah dan lobang". 23

Ganjarann yang akan diterima di alam akhirat menjadi pembicaraan yang memunculkan perbedaan pendapat dikalangan ulama. Mereka berbeda pendapat dalam hal substansi ganjaran yang akan diterima. Apakah ganjaran yang akan Allah berikan adalah berupa kesenangan dan kesengsaraan jasmani atau rohani?

Bey Arifin penulis buku Hidup Sesudah Mati berpendapat bahwa kehidupan di alam akhirat bukanlah hanya kehidupan rohani saja, melainkan kehidupan jasmani dan rohani. Oleh sebab itu ganjaran yang akan diterima di surga dan neraka juga berupa ganjaran rohani dan jasmani. Untuk memperkuat argumentasinya lebih jauh ia menguraikan perbedaan kehidupan di dunia dengan kehidupan di akhirat. Baginya kesenangan dan kesengsaraan di akhirat adalah kesengsaraan dan kesenangan yang disempurnakan, sedangkan kesenangan dan kesengsaraan di dunia adalah kesenagan dan kesengsaraan yang tak sempurna dan terbatas. Artinya, karena kesenangan di dunia meliputi kesenangan jasmani dan rohani, maka kesenangan dan kesengsaraan di kehidupan akhiratpun berupa kesenangan dan kesengsaraan jasmani dan rohani. ${ }^{24}$

Quraish Shihab dalam menjawab permasalahan di atas menuliskan bahwa kenikmatan dan kesengsaraan yang akan diberikan Allah adalah bersifat rohani dan jasmani. Namun demikian ia tidak menyalahkan atau mengkafirkan orang yang berpendapat bahwa ganjaran yang akan diterima hanyalah yang bersifat rohani (immateri), karena dia tidak menyangkal pendapat yang menyatakan bahwa kenikmatan rohani jauh melebihi kenikmatan jasmani. Untuk mendasari argumentasinya, 
ia menulis bahwa al-Qur'an dan sunnah seringkali member gambaran material tentang ganjaran yang akan diterima di akhirat. Sebagai contoh ia mengutip firman Allah yang melukiskan sungai-sungai di surga. Pada surat Muhammad ayat 15 dinyatakan, " perumpampamaan surga yang dijanjikan bagi orang yang bertaqwa, di sana terdapat sungai-sungai dari ai yang tiada berubah rasa dan baunya, sungai-sungai dari air susu yang tiada berubah rasanya, sungai-sungai dari khamar yang lezat rasanya bagi peminumnya, dan sungai-sungai dari madu yang disaring". Dari ayat tersebut, ia menjelaskan bahwa matsal berarti serupa bukannya sama. Oleh karena itu, deskripsi tentang surga yang menggunakan obyek-obyek duniawi tidak berarti sama dengan obyek-obyek yang dikenal di dunia. Persamaan obyek-obyek tersebut hanyalah pada nama, bukan pada substansi. ${ }^{25}$

Sedangkan kenikmatan indrawi adalah kenikmatankenikmatan yang dirasakan jasmani serta ruh dikembalikan ke dalam tubuh. Kenikmatan surgawi yang digambarkan secara jasamani dalam al-Qur'an menrupakan gambaran yang disukai oleh kebanyakan orang terhadap hal tersebut. Kebanyakan orang menganggap hal-hal tersebut adalah sesuatu yang mewah, lezat dan mendatangkan kelezatan dan kesenangan dalam pandangan mereka. Walaupun tentunya selera orang akan berbeda-beda dalam memandang kelezatan dan kenikmatan tersebut.

Dalam menjelaskan keterkaitan antara kenikmatan jasmani dan rohani, al-Ghazali menjelaskan bahwa apabila kenikmatan yang dirasakan oleh seseorang berlangsung terus menerus, maka ia tidak dapat lagi membedakan anatara kesenagnan jasmani dan kesenangan rohani. Ia beranggapan bahwa perasaan manusia dalam merasakan kenikmatan ada pada apa yang diilustrasikan, sedangkan ilustrasi tersebut ada pada daya fantasi dan indrawinya, bukan dari wujud eksistensi eksternalnya. Lebih jauh ia mengungkapakan bahwa jika kesenangan itu ditemukan dari sisi wujud eksternal, akan tetapi dalam indrawinya tidak ditemukan rasa kepuasan, bagi al-Ghazali hal sedemikian itu bukanlah kenikmatan. 
Pada kesimpulannya, al-Ghazali mengatakan bahwa kenikmatan akhirat tiada batasnya. Ia tidak dihalangi oleh ruang dan waktu, dan tidak ada yang mencegahnya, dan hal tersebut adalah perkara yang mungkin. ${ }^{26}$

Kebahagiaan sempurna dengan kenikmatan-kenikmatan yang tiada taranya di surga sebagaimana digambarkan dalam ayat-ayat al-Qur'an dan hadits-hadits Nabi, menimbulkan pertanyaan akan kebosanan dalam perisriwa yang dialami terusmenerus. Menanggapi hal ini, Quraish menjelaskan bahwa kebosanan tidak akan pernah menghinggapi mereka yang ada dalan surga. Ia menguraikan jawabannya dengan menyertakan kutipan ayat-ayar al-Qur'an. Baginya di surga tidak ada tidur, sebab tidur saudaranya mati, dengan demikian mereka selalu dalam kesibukan. (Q:S Yasin 36: 55).

Di dalam surga, para penghuni memeiliki kegiatan atau kesibukan yang beraneka ragam. Sewaktu-waktu mereka bercengkrama, di lain waktu mereka melihat-lihat keadaan nerak, melihat kenalannya di dunia. Hal ini dapa dilihat dari ayat-ayat berikut: "Salah seorang diantara mereka berkata:'sesungguhnya aku dahulu di dunia mempunyai teman yang berkata:'apakah engkau sungguh-sungguh termasuk orangorang yang membenarkan (hari Kebangkitan dan percaya) bahwa bila kita telah mati dan kita telah menjadi tanah dan tulang belulang apakah sesungguhny kita benar-benar (akan dibangkitkan) untuk diberi balasan?" Ia selanjutnya mengajak dengan berkata:'maukah kamu (wahai teman-teman penghuni surga) pergi meninjaunya( dan melihatnya di neraka?). Maka merekapun pergi “.(Q:S al-Shfat 37: 51-57).

Para penghuni surga juga akan bertem8u dengan pasangan dan anak cucu mereka karena keimanan mereka, sebagaimana disinyalir surat al-Thur 52 ayat 21, "Dan orang-orang yang beriman dan anak cucu mereka yang mengikuti mereka dalam beriman, akan kami pertemukan dengan anak cucu mereka...".

Di samping itu, dalam Q:S al-Rāa 13:23, "Surga 'And yang mereka masuk kedalamnya bersama-sama dengan orang-orang yang saleh dari bapak-bapaknya, istri-istrinya dan anak cucunya, sedang malaikat-malaikat masu ke tempat-tempat mereka dari semua pintu" 
Dari ayat tersebut dapat dipahami bahwa para malaikat akan dating silih berganti berdatangan masuk dari segala pintu surga sambil mengucapkan salam. Selai ayat tersebut, ada juga ayat yang mendukung akan perbedaaan yang akan mereka rasakan pada apa yang mereka dapatkan. Hal ini dapat ditelusiri pada Q:S al-Baqarah 2:25,"Dan sampaikanlah berita gembira kepa da mereka yang beriman dan berbuat baik, bahwa bagi mereka disediakan surga-surga yang mengalir sungai-sungai di dalamnya. Setiap mereka diberi rezeki buah-buahan dalam surga-surga itu, mereka mengatakan:"'nilah yang pernah diberikan kepada kami dulu." Mereka diberi buah-buahan yang serupa dan untuk mereka di dalam ada istri-istri yang suci dan mereka kekal di dalamnya".

Pada ayat tersebut dinyatakan bahwa para penghuni surga juga akan mendapatkan hidangan yang selalu berbeda-beda. Setiap mereka diberi hidangan, berupa buah-buahan atau lain sebagainya, mereka menduganya sama dengan hidangan sebelumnya, sehingga mereka berkata:"Ini yang telah dianugrahkan kepada kita sebelum ini". Tetapi sebenarnya tidaklah demikian, karena (mereka dianugrahi yang serupa) dalam bentuk atau warna dan jenisnya, tetapi sesungguhnya berbeda rasa dan kenikmatannya. ${ }^{27}$

Menurut al-Ghazali, di akhirat nanti Allah akan menambah selera penduduk surga dengan apa yang belum perbah terlintas dalam benak dan rasa manusia ketika mereka menjalani kehidupan dunia. Lebih jauh ia menjelaskan, bahwa di dunia manusia memiliki daya fantasi untuk menciptakan ilustrasi-ilustrasi. Ilustrasi-ilustrasi tersebut hanya ada dalam hayalan saja dan tidak dapat diwujudkan. Berbeda dengan apa yang manusia hasilkan dari daya fantasinya ketika di akhirat, apa yang menjadi ilustrasi daya fantasi, dapat langsung terwujud dan dinikmati. Pernyataan ini, merupakan penjelasan dari hadits Nabi yang menyatakan,:Sesungguhnya di surga terdapat pasar yang menjual ilustrasi-ilustrasi". Selain itu ia juga menambahkan, bahwa kenikmatan akhirat tidak terbatas dengan ruang dan waktu, sehingga apabila ada seribu orang yang berada pada tempat yang berlainan ingin menyaksikan sesuatu dalam 
waktu dan kondisi yang sama tentu mereka akan bisa menyaksikan seperti apa yang terbersit di benak mereka dalam tempat yang berbeda. ${ }^{28}$

Dari beragam ayat al-Qur'an dan hadits Nabi, tampaknya ganjaran kenikmatan yang akan diberikan cenderung ditujukan kepada kaum pria, sedangkan kenikmatan untuk kaum wanita tidak dijelaskan dengan gambling, Artinya ada ketidak seimbangan dalam penjelasan ganjaran yang akan didapat antara pria dan wanita.

Mengomentari hal yang sedemikian itu, Quraish menjelaskan bahwa al-Qur'an dan sunah Nabi menggunakan istilah-istilah gender yang sangat istimewa dan unik yang mencakup pria dan wanita. Ia memberikan contoh kata azwaj, yang biasanya diterjemahkan oleh orang Indonesia dengan arti istri-istri, adalah terjemahan yang keliru. Menurutnya kata azwaj adalah bentuk plural dari kata zauj yang memiliki arti pasangan. Dengan demikin janji Tuhan kepada para penghuni surga akan ganjaran azwaj muthahharah mencakup untuk lelaki dan perempuan. Sedangkan kata muthahharah selain memiliki arti suci dari haid yang hanya dialami oleh kaum hawa kata tersebut juga mencakup arti suci dan bersih dari segala dosa dan noda, termasuk kesucian hati dan pikiran.

Demikian juga dengan istilah hūr 'ain, yang oleh kebanyakan orang Indonesia diartikan bidadari. Istilah tersebut adalah kata majemuk yang berdiri dari kata hur dan 'ain. Kata pertama dalah bentuk plural dari kata haura dan ahwar. Kata haura merujuk kepada jenis feminine, sedangkan kata ahwar adalah maskulin. Artinya akat hur adalah merupakan bentuk plural dari dua kata ini, merupakan kata netral kelamin, bisa digunakan untuk menunjukkan lelaki ataupun perempuan. Oleh sebab itu, dari penjelasan di atas, istilah hur 'ain tidak tepat kalau diartikan bidadari.

Lebih jauh ia menerangkan bahwa kata hur diambil dari kata dasar yang berarti tampaknya sedikit keputihan pada mata disela kehitamannya (artinya, yang putih pada mata sangat putih, dan yang hitam pun sangat hitam), atau kata tersebut bisa juga diartikan bulat, namun sebaliknya bisa juga diartikan sipit. 
Kata 'ain adalah bentuk plural dari kata 'aina yang menunjukan faminin dan 'ain yang menunjukkan maskulin. Arti kedua kata tersebut adalah bermata besar dan indah. Jadi, kata hur 'ain yang merupakan kata netral kelamin, jika diartikan secara leterlek berarti seseorang (baik lelaki atau perempuan) yang bermata lebar atau sipit. Dialah yang menjadi pasangan di surga. Sedangkan kalau diartikan secara majazi, kata tersebut berarti seseorang yang sipit matanya dalam arti kecil, sehingga dia tidak melihat kecuali kepada pasangannya. Dan akata-kata tersebut bisa juga diartikan dengan orang yang lebar matanya sehingga selalu terbuka dan memandang penuh perhatian kepada pasangannya itu.

Dari uraian di atas, Quraish menyimpulkan bahwa alQur'an sengaja memilih kata majemuk untuk mengakomodasi segala selera keindahan, ghirah, dan kecemburuan dan perhatian yang penuh. Artinya, bagi mereka yang memiliki selera kepada yang bermata sipit, mereka akan mendapatkannya, pada kata tersebut, demikian pula dengan mereka yang senang dengan yang bernata lebar dan bulat, juga akan mendapatkannya pada kata itu. Sedangkan dalam artian majazi, mereka yang pencemburu, akan mendapatkan pasangan yang sipit, yaitu pasangan yang tidak akan melihat orang lain kecuali padanya. Hal yang demikian itu sesuai dengan apa yang Allah firmankan dalam surat Fushilat 41:31,"Bahwa di surga kamu akan memperoleh apa yang kamu inginkan dan memperoleh pula apa yang kamu minta., 29

Lebih jauh dalam menguraikan kenikmatan yang akan diperoleh penghuni surga, al-Ghazali mengutip ayat al-Qur'an dari surat Yunus ayat 26, "Bagi orang-orang yang berbuat baik ada pahala yang terbaik (surga) dan tambahan.....". Dari ayat tersebut ia mengambil kesimpulan bahwa kenikmatan tertinggi di akhirat adalah melhat Allah. Kenikmatan tertinggi itu merupakan interpretasi dari arti kata ziyadah (tambahan), alGhazali menyebutkan bahwa tambahan yang akan Allah berikan adalah puncak pahala terbaik dan akhir kenikmatan. Untuk menguatkan argumentasinya akan hal tersebut, ia menuliskan sebuah hadits Nabi yang diriwayatkan oleh Musli, "Lalu hijab 
diangkat dan mereka memandang kepada wajah Alla swt. Maka tidaklah mereka diberi sesuatu yang lebih disukai oleh mereka dari pada memandang kepadaNya". 30

\section{Konsep Neraka dalam Perspektif Al-Ghazali 1. Pengertian dan Kondisi Fisik Neraka}

Term neraka adalah kata yang dipakai dalam bahasa Indonesia yang merupakan tarjemahan yang berasal dari kata bahasa Arab al-Nār. Pemahaman neraka yang umum dipahami ialah tempat tinggal yang disediakan Allah untuk orang-orang yang tidak beriman kepadaNya. Yaitu orang-orang yang menentang aturan-aturanNya dan tidak mempercayai rasulNya. Ia juga merupakan tempat untuk menghukum musuh-musha Allah dengan siksaaan yang amat dahsyat dan hina, sehingga tidak ada tempat yang lebih buruk darinya. Pemaham ini dapat didasari dari firman Allah dalam Q:S al-Taubah 9: 63, "Tidakkah mereka mengetahui bahwa siapa yang menentang Allah dan rasulNya, maka sesungguhnya neraka jahanamlah baginya, ia kekal di dalamnya. Itu adalah kehinaan yang besar". Demikian pula dalam surat al-Shād 38: 55-56, “ Beginilah (keadaan mereka). Dan sesungguhnya bagi orang-orang yang durhaka benar-benar disediakan tempat kembali yang buruk. Yaitu neraka jahannam, yang mereka masuk ke dalamnya, amatlah buruk jahannam itu sebagai tempat tinggal., 31

Al-Ghazali sendiri tidak memberikan definisi yang pasti akan arti neraka. Ia hanya menyebutkan bahwa neraka adalah negeri yang dikenal akan kesengsaraan dan kepedihan. ${ }^{32}$ Namun dari keterangan yang diberikannya dapat ditarik kesimpulan bahwa neraka adalah tempat yang amat menakutkan dan mengerikan yang disediakan untuk menyiksa orang-orang yang mengingkri Allah. Ia juga menggambarkan bahwa neraka merupakan lembah yang bercabang-cabang. Stateent ini ia ambil dari hadits Nabi yang berbunyi, "sesungguhnya di neraka jahanam ada tujuh puluh ribu lembah. Pada setiap lembah terdapat tujuh puluh ribu cabang. Pada setiap cabang terdapat 70.000 ular dan 70.000 kalajengking..."33

Ada tujuh tingkatan yang berbeda bagi neraka, di mana kedahsyatan siksaannya berbeda antara satu dan lainnya. Nama- 
nama neraka tersebut adalah: 1. Neraka jahannam, 2. Neraka Saqar, 3. Neraka Ladha, 4. Neraka Huthamah, 5. Neraka Sa'ir, 6. Neraka Jahim, 7. Neraka Hawiyah. Namun demikian alGhazali tidak mendefinisikan dan menjabarkan pembagian tingkatan neraka tersebut dengan detail. Di samping itu, walaupun ia membagi tingkatan neraka menjadi tujuh tingkatan, namu ia tidak merinci macam-macam siksaan yang akan diterima dan dialami oleh para penghuni surga secara rinci, sesuai dengan pembagian tujuh tingkatan neraka. Hal ini berkaitan dengan pernyataannya, bahwa dalam menjelaskan siksaan neraka itu ia hanya menjelaskan secara global, karena untuk merinci setiap adzab yang hanya berisikan kesedihan, kesusahan, dan kesengsaraan tidak akan pernah ada habishabisnya. $^{34}$ Namun demikian, dalam pembicaraan yang berkaitan dengan siksaan di neraka, al-Ghazali menyatakan bahwa siksaan yang akan diterima oleh penghuninya berbedabeda sesuai dengan kemaksiatan dan dosa-dosa yang telah diperbuat pada kehidupan dunia. Pandangan ini menurutnya berkaitan dengan keadilan Tuhan. Bahwa Tuhan yang Maha Adil tidak akan menzalimi hambanya. Sesuai dengan hadits yang diriwatkan oleh Bukhari dan Muslim, ia berkeyakinan bahwa tingkatan yang paling ringan dari siksa neraka ialah apabila seseorang memakai dua sandal dari apai neraka, maka otaknya akan mendidih karena panasnya ke dua sandal tersebut. $^{35}$

\section{Gambaran Siksa Neraka}

Gambaran penyiksaan yang akan dialami oleh manusia sebagaimana dijelaskan oleh al-Ghazali adalah gambaran siksaan jasmani dan rohani. Ia mengungkapkan bahwa di neraka kelak manusia akan mengalami siksaan yang amat dahsyat sehingga muka mereka menjadi hitam melebihi hitamnya api yang sangat panas, maka mereka menjadi buta, lisan mereka menjadi bisu, punggung mereka hancur, tulang belulang mereka pecah, kulit mereka terkoyak-koyak, dan tangan mereka dibelenggu sampai leher mereka. Sementara itu ular-ular dan kalajengking neraka menggelayuti tubuh mereka. 
Siksaan neraka tidak saja hanya yang tersebut di atas, selanjutnya al-Ghazali menambahkan bahwa para pembuat dosa akan ditempatkan di neraka yang panas, dan diberi minuman yang panas. Pada keterangan lain ia menyebutkan bahwa orangorang yang berdosa akan merasakan penyesalan yang hebat, dan kesedihan yang tak terhingga. Mereka akan disiksa dengan gambaran siksaan yang mengerikan. Mereka akan dibelenggu dengan keadaan tertelungkup, dan ditenggelamkan dalam api neraka. Makanan, minuman, pakaian dan tempat tidur mereka adalah api neraka. Selain itu mereka akan disiksa dengan pukulan alat pemukul besi dan dirantai dengan rantai yang amat berat, yang apabila dipukulkan ke kepala mereka maka dahi mereka akan menjadi remuk redam, terpancarlah nanah dari mulut mereka dan terputus jantung mereka. Biji mata mereka akan terlepas, dan seluruh anggota badan, daging, rambut dan kulit mereka akan menjadi lumat. Mereka juga akan disiram dengan air panas di kepala mereka, setiap kulit mereka masak, maka kulit tersebut akan diganti dengan yang baru. Karena siksaan yang demikian pedih, mereka mengharapkan kematian, namu mereka terus dihidupkan. ${ }^{36}$

Penjelasan akan neraka dan siksaannya yang amat dahsyat dan mengerikan, yang terdapat dalam ayat-ayat alQur'an dan hadits-hadits Nabi, merupakan pelajaran moral, dan peningkatan keimanan yang amat berharga bagi manusia untuk memperbaiki diri dalam menjalankan kehidupan di dunia. Untuk iti Al-Ghazali menasehatkan pembacanya untuk berfikir dan merenungi lebih dalam, dan mengobarkan rasa takut yang terkuak dari dalam hati ketika bersentuhan dengan hal-hal yang berkaitan dengan siksa neraka. ${ }^{37}$

Siksaan neraka yang demikian dahsyat dan mengerikan dapat ditelusuri dari ayat-ayat al-Qur'an sebagai berikut: Dalam Q:S al-Ma'arij 70:15, "Neraka adalah apai yang berkobar, mengelupaskan kulit kepala", dalam Q:S al-Humazah 104: 69,'Dia adalah apai yang disiapkan Allah, berkobar dan (membakar) sampai ke hati (yang dibakarnya_, dia ditutup rapat atas mereka (sehingga mereka tidak dapat mengelak, apabila) mereka diikat pada tiang-tiang yang panjang,". Di Q:S al-Mulk 67:8 disebutkan bahwa neraka sangat geram terhadap setiap 
makhluk yang dimasukkan ke dalamnya," Hampir-hampir ia terpecah-pecah akibat kemarahannya". Di samping itu neraka tidak akan pernah kenyang terhadapa apa yang dimasukkan ke dalamnya. Seberapapun banyak yang dijerumuskan ke dalamnya, tempat penyiksaan ini tidak berhenti merasa haus. Hal tersebut dapat terlihat pada Q:S qaf 50: 30, "Pada hari itu (malaikat-malaikat) Kami bertanya pada neraka jahannam:'Apakah engkau telah penuh?' Dia menjawab:”Masih adakah tambahan?. Hal senada juga dapat dilihat pada hadits Nabi yang diriwayatkan oleh Imam Muslim, " Jahanam akan terus menerus berkata:"Masih adakah tambahan sampai Rabb al'Izzah (Tuhan yang Maha MUlia) meletakkan kakiNya sehingga terdesak sampai kepinggir isinya satu sama lain, dan nerakapun berkata: qath, qath". Hadits ini mengilustrasikan kehausan neraka terhadap para pendurhaka. ${ }^{38}$

Bagi al-Ghazali, sebagaimana ia merujuk kepada sebuah hadits yang diriwatkan oleh muttaffaq 'alaih dari al-Nu'aim ibn Basyar, siksa neraka yang teringan ialah, apabila seseorang memakai sandal dan sandal tersebut menginjak api neraka, maka otaknya akan mendidih karena panasnya.

\section{Makanan dan Minuman Penghuni Neraka}

Dalam mengelaborasi permasalahan yang berkaitan dengan neraka, Al-Ghazali tidak saja berbicara tentang siksaan yang pedih, namun juga ia menjelaskan hal-hal yang terkait dengan unsure-unsur yang berhubungan dengannya. Namun demikian, dalam upaya ini ia merujuk pendapatnya pada ayatayat al-Qur'an dan hadits-hadits yang berkaitan dengan neraka.

Berkenaan dengan makanan dan minuman yang akan diperoleh oleh para penghuni neraka, al-Ghazali merujuk kepada ayat-ayat al-Qur'an dan menjelaskan dengan pengertian yang tak jauh berbeda dengan apa yang termaktub di dalamnya. Artinya ia tidak menginterpretasi ayat-ayat tersebut dengan makna-makna kiasan atau member penjelasan dengan analogianalogi. Dengan kata lain, ia menjelaskan ayat-ayat tersebut sebagaimana yang termaktub di dalamnya tanpa bantahan dan interpretasi yang rumit. 
Hal tersebut dapat dilihat dalam upayanya mengelaborasi ayat-ayat al-Qur'an dan Hadits Nabi yang dijadikan sebagai sandarannya. Baginya, orang-orang yang dimasukkan ke dalam neraka akan diberi makanan yang bernama ghislin, yakni darah dan nanah sebagaimana terdapat dalam Q:S al-Haqqah 69: 36,'Dan tidak ada makanan kecuali dari ghisilin", dan dalam Q:S al-Ghasyiyah, mereka akan diberi makanan dhari', yaitu" makanan dari pohon berduri yang tidak menggemukkan dan tidak pula menghilangkan lapar”. Dalam Q:S al-Shaffat, disebutkan para penghuni neraka akan mendapatkan zaqqum, yaitu"pohon yang keluar dari dasar neraka jahannam". Mereka juga akan diberi kotoran minyak yang mendidih di dalam perut, seperti mendidihnya air yang sangat panas.

Sedangkan minuman penghuni neraka, sebagaimana yang dijelaskan al-Ghazali adalah minuman yang berupa air yang sangat panas yang diambil dari sumber yang amat panas pula. Hal ini ia sandarkan pada Q:S al-Ghasyiah 88: 4-5. Selain itu mereka juga akan diberi minuman berupa nanah, sebagaimana termaktub dalam Q:S Ibrahim 14:17." Diminumnya air nanah itu dan hampir dia tidak bisa menelannya dan datanglah (bahaya) maut kepadanya dari segenap penjuru, tetapi dia tidak juga mati; dan di hadapannya masih ada azab yang berat". Selain ayat-ayat al=Qur'an, al-Ghazali juga mengutip hadits Nabi untuk menjelaskan minuman para penghuni neraka. Ia mengutip hadits yang diriwayatkan oleh alTirmidzi," Kelaparan dilemparkan kepada para penghuni neraka, sehingga ia memalingkan apa yang mereka ada padanya dari adzab, lalu mereka meminta makanan. Lalu mereka diberi makanan dari kayu yang berduri yang tidak menggemukkan dan tidak dapat melepaskan kelaparan. Dan mereka meminta makanan, lalu diberi makanan yang mencekikkan dengan minuman. Lalu mereka meminta minuman, lantas diangkat kepada mereka air yang sangat panas dengan besi-besi yang bengkok. Maka apabila besi bengkok itu mendekati mereka niscaya membakar muka-muka mereka. Apabila minuman memasuki perut mereka, niscaya minuman itu memotongmotong apa yang ada dalam perut maereka..."39 


\section{Penutup}

Dari paparan di atas, dapat ditarik kesimpulan bahwa bagi al-Ghazali surga dan neraka adalah tempat manusia di kehidupan akhirat. Surga baginya tempat yang penuh kesenangan sedangkan neraka tempat penuh siksaan dan kesengsaraan. Balasan dan siksaan yang diterima di akhirat dijabarkan al- Ghazali dengan detail, dan itu akan dirasakan oleh penghuni surga dan neraka secara jasmani dan rohani. Penjelasan detail yang dipaparkannya, tampaknya tak terlepas dari interpretasi beliau terhadap ayat-ayat al-Qur'an dan haditshadits Nabi yang diyakini kebenarannya. Wallahu a'lam bil alshawab.

13.

${ }^{1}$ H. Bey Arifin, Hidup sesudah Mati, (Jakarta: C. V. Kinta, 1991), h.

2 Syed Ameer Ali, Api Islam, terj. H. B. Jassin, (Jakarta: Bulan Bintang, 1978), h. 334.

${ }^{3}$ Sayid Qutub, Hari Akhir Menurut Al-Qur'an, terj. H. Abdul Aziz, (Jakarta : Pustaka, 1986), h. 3.

${ }^{4}$ Sayid Qutub, Hari Akhir Menurut Al-Qur'an, h. !!-12

5 James Hastings, Ensiclopedia of Religion and Ethics, vol. V, (New York, 1912), h. 376-379

${ }_{7}^{6}$ Sayid Qutub, Hari Akhir Menurut Al-Qur'an, h. 27-29

7 Jane Idelman Smith, Maut, Barzakh, Kiamat, Akhirat: Ragam Pandangan dari Klasik hingga Modern, (Jakarta: Serambi, 2004), h. 146.

${ }^{8}$ Hasyimsyah Nasution, Filsafat Islam, (Jakarta: Gaya Media Pratama, 1999), h. 86.

9 Abu al-Wafa' al Ghanimi, Sufi dari Zaman ke Zaman, terj. Ahmad Rof'I Utsmani, (Bandung: Pustaka, 1985). H. 148.

${ }^{10}$ Abdul Qayyum, Surat-Surat Al-Ghazali kepada Para Penguasa, Pejabat Negara dan Ulama Sezamannya, terj. Haidar Baghir, (Bandung: Mizan, 1983), h. ix

${ }^{11}$ Kautsar Azhari Noer, "Mengkaji Ulang Posisi Al-Ghazali dalam Sejarah Tasawuf”, Paramadina, Vol. I, No. 2, 1999, h. 164.

${ }^{12}$ Moh. Abdai Rathomy, KIamat, (Bandung: PT Alma'arif, 1983), h. 172

${ }^{13}$ Muhammad Ibn Mandzūr, Lisān al- 'Arab, Juz XIII, (Bayrūt: Dār Sādir), h. 100.

${ }^{14}$ Imam al-Ghazali, Ihyā' 'Ulūm al-Dīn,(Mishr: Dār al-Hay, tt), h.519. 
15 Muhammad Abdul Halim, Menafsirkan al-Qur'an dengan alQur'an: Memahami al-Qur'an dengan Metode, terj. Rofiq Suhud (Ujung Berung: Nuansa, 2008), h. 131.

${ }_{17}^{16}$ Abdai Rathomi, Kiamat, h. 172-175.

${ }^{17}$ Al-Ghazali, Ihyā' 'Ulūm al-Dīn, h. 519. Lihat M. Quraish Shihab, Perjalanan Menuju Keabadian: Kematian, Surga dan Ayat-ayat Tahlil, (Jakarta: Lentera Hati, 2001), h. 156. Lihat juga H. Oemar Bakry, Tafsir Rahmat, (Jakarta: Mutiara, 1984), h. 1069

${ }_{18}^{18}$ Al-Ghazali, Ihyā' 'Ulūm al-Dīn, h. 519-520

${ }^{19}$ Al-Ghazali, Ihyā' 'Ulūm al-Dīn, h. 519-520

${ }^{20}$ Al-Ghazali, Ihyā' 'Ulūm al-Dīn, h. 522.

${ }^{21} \mathrm{Al}-\mathrm{Ghazali}$, Ihyā' 'Ulūm al-Dìn, h. 523

${ }^{22}$ Al-Ghazali, 524.

${ }^{23}$ Al-Ghazali, Ihyā' 'Ulūm al-Dìn, h. 527.

${ }^{24}$ H. Bey Arifi, Kehidupan Sesudah Mati, (Jakarta: CV. Kinta, 1991), h. 269 .

${ }^{25}$ Shihab, Perjalanan Manuju, h. 165-166

${ }^{26}$ Al-Ghazali, Majmu'ah Rasāil al-Imām al-Ghazalī, (Beirut: Dār alKutb al-'Ilmiyyah, 1993), h. 111-113.

${ }^{27}$ Shihab, Perjalanan, h. 161-162

${ }^{28}$ Al-Ghazali, Majmu'ah Rasail, h. 113.

${ }^{29}$ Quraish, Perjalanan, h. 162-165

${ }^{30}$ Al-Ghazali, Ihyā 'Ulūm al-Dīn, h. 528

${ }^{31}$ Umar Sulaiman al-Asyqar, Surga dan Neraka (Jakarta: PT Serambi Ilmu Semesta, 2000), h. 17

32 Imam al-Ghazali, Menyingkap Hati, menghampiri Ilahi: Ziarah Ruhani bersama Imam Al-Ghazali, (Bandung: Pustaka Hidayah), 307.

${ }^{33}$ Al-Ghazali, Ihyā' 'Ulūm al-Dìn, h. 514.

${ }^{34}$ Al-Ghazali, Ihyā' 'Ulūm al-Dīn, h. 518.

${ }^{35}$ Al-Ghazali, Ihyā' 'Ulūm al-Dīn, h. 295.

${ }^{36}$ Al-Ghazali, Ihyā' 'Ulüm al-Dīn, h.514.

${ }^{37}$ Al-Ghazali, Ihyā' 'Ulūm al-Dīn, h.519.

${ }^{38}$ Quraish Shihab, Perjalanan Menuju, h. 142-143

${ }^{39}$ Al-Ghazali, Ihyā' 'Ulūm al-Dìn, h.516. 


\section{REFRENSI}

Ali, Syed Ameer, Api Islam, terj. H. B. Jassin, Jakarta: Bulan Bintang, 1978

Arifin, H. Bey, Hidup sesudah Mati, Jakarta: C. V. Kinta, 1991

.............., Kehidupan Sesudah Mati, Jakarta: CV. Kinta, 1991

Asyqar, al Umar Sulaiman, Surga dan Neraka Jakarta: PT Serambi Ilmu Semesta, 2000,

Bakry, H. Oemar, Tafsir Rahmat, Jakarta: Mutiara, 1984

Ghanimi, Abu al-Wafa' al, Sufi dari Zaman ke Zaman, terj.

Ahmad Rof'I Utsmani, Bandung: Pustaka, 1985

al-Ghazali, Imam, Ihyā' 'Ulūm al-Dīn, Mishr: Dār al-Hay, tt

Menyingkap Hati, menghampiri Ilahi:

Ziarah Ruhani bersama Imam Al-Ghazali, (Bandung:

Pustaka Hidayah,tt

Majmu'ah Rasāil al-Imām al-Ghazalī,

Beirut: Dār al-Kutb al-'Ilmiyyah, 1993

Halim Muhammad Abdul, Menafsirkan al-Qur'an dengan al-

Qur'an: Memahami al-Qur'an dengan Metode, terj. Rofiq Suhud Ujung Berung: Nuansa, 2008

Hastings. James, Ensiclopedia of Religion and Ethics, vol. V, New York, 1912

Nasution, Hasyimsyah, Filsafat Islam, Jakarta: Gaya Media Pratama, 1999

Qutub, Sayid, Hari Akhir Menurut Al-Qur'an, terj. H. Abdul Aziz, Jakarta : Pustaka, 1986.

Smith, Jane Idelman, Maut, Barzakh, Kiamat, Akhirat: Ragam Pandangan dari Klasik hingga Modern, (Jakarta: Serambi, 2004),

Abdul Qayyum, Surat-Surat Al-Ghazali kepada Para Penguasa, Pejabat Negara dan Ulama Sezamannya, terj. Haidar Baghir, Bandung: Mizan, 1983. 
66 | Hanafi , Surga Dan Neraka Dalam Persepsi Al-Ghazali..........

Kautsar Azhari Noer, "Mengkaji Ulang Posisi Al-Ghazali dalam Sejarah Tasawuf", Paramadina, Vol. I, No. 2, 1999, h. 164

Rathomy. Moh. Abdai, KIamat, Bandung: PT Alma'arif, Muhammad Ibn Mandzūr, Lisān al- 'Arab, Juz XIII, Bayrūt: Dār Sādir

M. Quraish Shihab, Perjalanan Menuju Keabadian: Kematian, Surga dan Ayat-ayat Tahlil, Jakarta: Lentera Hati, 2001 